\title{
MODEL KEPEMIMPINAN DAN PENGEMBANGAN KREATIVITAS DALAM PENGELOLAAN DESTINASI WISATA BUDAYA SAUNG ANGKLUNG UDJO
}

Budiman Mahmud Musthofa

Program Pendidikan Vokasi Universitas Indonesia, email: budimanmm@gmail.com

\begin{abstract}
ABSTRAK
Histori Artikel

Submitted:

5 Februari 2020

Reviewed:

5 Februari 2020

Accepted:

31 Agustus 2020

Published:

15 November 2020

Globalisasi budaya yang berbembang dengan cepat memberikan banyak dampak bagi budaya lokal di Indonesia. Dinamika perkembangan dan kemunduran pengelolaan budaya menarik untuk dikaji mengingat di era ekonomi kreatif saat ini budaya kembali menjadi modal utama yang mampu menggerakkan perekonomian masyarakat yang salah satunya melalui pengembangan destinasi wisata budaya. Pengelolaan destinasi wisata dan berbagai atraksi memerlukan kepemimpinan, kreativitas dan dukungan dari budayanya. Kajian ini dilakukan melalui metode kualitatif untuk menggali informasi mendalam tentang model kepemimpinan dan pengembangan kreativitas dalam pengelolaan destinasi wisata budaya melalui studi kasus Saung Angklung Udjo. Hasil Penelitian ini menunjukan bahwa kepemimpinan dalam pengelolaan destinasi wisata budaya memerlukan kekuatan kreatif dan dukungan dari masyarakat dan budayanya agar mencapai keberhasilan dan berkelanjutan secara jangka panjang. Terbukti, selama lebih dari 54 tahun Saung Angklung Udjo terus berkembang dan memberikan banyak kontribusi bagi masyarakat dan pelestarian budaya Sunda serta menjadi kebanggaan nasional di pentas global.
\end{abstract}

Kata Kunci: Kepemimpinan, destinasi wisata budaya, globalisasi, kreativitas

\section{LEADERSHIP MODEL AND CREATIVITY DEVELOPMENT OF CULTURAL TOURISM DESTINATION MANAGEMENT OF SAUNG ANGKLUNG UDJO}

\begin{abstract}
The rapid cultural development affected by globalization has had many impacts on local cultures in Indonesia. The dynamics of development and setback of cultural management are interesting to study considering that in the current era of the creative economy, culture is the main capital capable of driving the community's economy, one of which is through the development of cultural tourism destinations. Management of tourist destinations and various attractions requires leadership, creativity and support from its culture. This study was conducted through a qualitative method to explore in-depth information about the leadership model and the development of creativity in the management of cultural tourism destinations through case study of Saung Angklung Udjo. This research shows that leadership in managing cultural tourism destinations requires creative strength and support from the community and culture in order to achieve long-term success and sustainability. Evidently, for more than 54 years Saung Angklung Udjo has continued to grow and contribute to society and preserve Sundanese culture and become a national pride on the global level.
\end{abstract}

Keywords : Leadership, cultural tourism destination, globalization, creativity 


\section{PENDAHULUAN}

Kepemimpinan merupakan aspek yang selalu menarik untuk dikaji dan tidak akan pernah selesai dalam pembahasannya. Pada konteks sosiokultural, kepemimpinan merupakan posisi sentral yang secara langsung berpengaruh terhadap keberlangsungan kehidupan dalam masyarakat/komunitas ataupun organisasi. Di era global saat ini, aspek kepemimpinan semakin penting untuk dikaji karena seorang pemimpin selain memahami aspek lokal juga harus memahami perkembangan global.

Pada konteks kebudayaan, saat ini kita sedang berada di era globalisasi budaya yang memberikan berbagai dampak baik postifif maupun negatif terhadap eksistensi budaya local (Ife, 2013). Berbagai dampak ini misalnya adanya penguatan kreativitas budaya untuk pengembangan ekonomi kreatif, komodifikasi yang berlebihan, identitas asli yang terancam hilang. Adanya fakta bahwa berbagai bentuk kebudayaan di Indonesia termasuk seni tradisi yang memudar, hilang dan punah akibat globalisasi budaya mengharuskan kita untuk melakukan upaya preventif dan kreatif dalam menyelamatkannya.

Pada sisi lain, juga ada beberapa fakta menarik bahwa ternyata seni tradisi asli Indonesia mampu mendunia dan mengglobal, seperti batik, wayang, gamelan, angklung dan beberapa seni tradisi lainnya. Keberhasilan atas pengembangan budaya dan seni tradisi yang mendunia ini tentunya menarik untuk menjadi bahan kajian tentang bagaimana budaya lokal mampu eksis, berkembang hingga mendunia dan memberikan dampak besar bagi masyarakat dengan hadirnya industri pariwisata dan ekonomi kreatif. Perkembangan ekonomi kreatif ini telah menjadi tumpuan pergerakan ekonomi nasional.

Kajian ini mencoba untuk menggali bagaimana kekuatan kepemimpinan dan kreativitas seorang pemimpin dalam mengelola budaya menjadi daya tarik wisata dan bagaimana seorang pemimpin mengelola destinasi di saat krisis, termasuk saat krisis tahun 1998 dan saat pandemi Covid-19. Penulis menggunakan studi kasus destinasi wisata budaya Saung Angklung Udjo yang berlokasi di Bandung, Jawa Barat. Saung Angklung Udjo (SAU) memiliki sejarah yang panjang sebagai destinasi wisata budaya.

SAU didirikan pada tahun 1966 oleh Udjo Ngalagena di Bandung. Hingga saat ini, perkembangannya sudah sangat besar dan mampu mengantarkan angklung ke level dunia. Sebelum pandemik Covid-19, kunjungan wisatawan pertahun kurang lebih 250.000 orang dengan partisipasi masyarakat lokal yang mencapai 1.000 orang. Meskipun kawasan sekitar SAU sudah menjadi perkotaan, namun suasana perdesaan masih dijaga dan menjadi kekhasan yang ditawarkan oleh pengelola (Musthofa, 2019). Keberhasilan kepemimpinan dan pengelolaan kreatif di Saung Angklung Udjo ini kiranya dapat memberikan inspirasi bagi masyarakat dalam membangun dan mengelola destinasi wisata budaya di tempat lainnya.

\section{LITERATUR REVIEW}

Kepemimpinan merupakan kemampuan mempengaruhi suatu kelompok ke arah pencapaian tujuan (Robbin, 2017). Guna melengkapi dan mempertajam kajian ini, maka penulis akan menggunakan konsep otoritas atau kekuasaan yang terkait dengan kepemimpinan dan kekuasaan pimpinan. Weber (Ritzer, 2004) menjelaskan otoritas atau kekuasaan sebagai suatu kemungkinan dimana seseorang akan ditaati atas dasar suatu kepercayaan akan legitimasi haknya untuk mempengaruhi. Ada tiga tipe sistem otoritas, yaitu tradisional, kharismatik dan legal rasional.

Otoritas tradisional adalah tipe otoritas yang berlandaskan pada tradisi, kebiasaan, kekuatan zaman dulu dan kesakralan aturan. Otoritas kharismatik adalah otoritas yang didasarkan pada kemampuan atau karakteristik luar biasa yang dimiliki seorang pemimpin sehingga memberikan inspirasi pada pengikutnya. Sedangkan otoritas legalrasional biasanya ada di masyarakat modern, yaitu otoritas yang didasarkan pada 
seperangkat peraturan yang diundangkan secara resmi dan rasional. (Ritzer, 2004).

Kreativitas adalah kemampuan untuk memberikan gagasan baru yang dapat diterapkan dalam pemecahan masalah, atau sebagai kemampuan untuk melihat hubungan-hubungan baru antara unsur-unsur yang sudah ada sebelumnya (Munandar, 2012). Kreativitas pada konteks sosial budaya lahir dari suatu kondisi dan potensi individu dalam interaksinya dengan lingkungan masyarakat dan budayanya (Soemardjan, 1983). Berbagai kreasi berpotensi untuk mudah diterima masyarakat jika mengacu pada tradisi lamat atau tidak bertentangan dengan tradisi yang sudah ada (Gunawijaya, 2011). Suatu kreasi yang telah diterima dapat berkembang menjadi tradisi jika memberikan efek/dampak bagi masyarakat (Gunawijaya, 2011; Shahab, 2004).

Kajian mengenai kepemimpinan, kreativitas dan tradisi yang dalam hal ini difokuskan pada invensi tradisi. Invensi tradisi adalah salah satu upaya merancang kondisi sosial budaya atau aktivitas budaya dan lingkungan yang mengacu pada tradisi lama yang dikemas kembali kemudian diformalkan dan diekpresikan secara rutin dan menjadi ritual masyarakat pendukungnya (Hobsbawm, 2000).

Pada konteks lokal ke-Indonesiaan, kajian yang cukup relevan dengan pembahasan ini adalah kajian yang dilakukan oleh Shahab (2001; 2004) tentang rekonstruksi tradisi Betawi, Gunawijaya (2011) tentang invensi tradisi masyarakat kasepuhan gunung halimun, Moersid (2013) tentang reinvensi batik sebagai tradisi 'otentik' yang selalu dapat dikonstruksi atau dire-konstruksi, demi kepentingan politis ataupun pariwisata. Rahmanisa (2014) tentang invensi tradisi dan pariwisata, Musthofa (2017) tentang invensi tradisi lokal Saung Angklung Udjo yang mendunia.

Hobsbawm (2000), Shahab (2001; 2004), Gunawijaya (2011) melihat bahwa peran inisiator kreatif sangat penting dalam proses penciptaan suatu tradisi (invensi tradisi).
Invensi tradisi tidak dapat dipisahkan dari dimensi kekuasaan dan kepemimpinan inisiator kreatif. Masood (2011) melihat bahwa kreativitas memerlukan kepemimpinan dan inovasi. Menurutnya, individu yang kreatif memberikan dampak bagi organisasi dan mendorong kesuksesan jangka panjang.

Daya Tarik Wisata adalah segala sesuatu yang memiliki keunikan, keindahan, dan nilai yang berupa keanekaragaman kekayaan alam, budaya, dan hasil buatan manusia yang menjadi sasaran atau tujuan kunjungan wisatawan (UU No 10 tahun 2009). Wisata budaya adalah perpindahan orang ke tempattempat wisata budaya yang jauh dari tempat tinggal normalnya, dengan maksud untuk mengumpulkan informasi dan pengalaman untuk memenuhi kebutuhan budaya mereka (Richard, 1996).

\section{METODE}

Penelitian ini menggunakan metode kualitatif dengan studi kasus dan bersifat penelitian eklapanasi. Penelitian eksplanatoris bertujuan untuk menjelaskan alasan terjadinya peristiwa dan untuk membentuk, memperdalam, serta mengembangkan teori (Creswell, 2010; Neuman, 2013). Penelitian di lakukan di Saung Angklung Udjo yang berada di Jalan Padasuka No 118, Bandung, Jawa Barat. Data primer didapat melalui observasi dan wawancara dengan indorman lebih dari 20 orang yang meliputi berbagai peran seperti direktur, manajer, pengrajin, pemain dan amsyarakat. Data sekunder didapatkan melalui studi pustaka, analisis dokumen, website, dan berbagai sumber sekunder lainnya.

\section{HASIL DAN PEMBAHASAN}

\section{Kepemimpinan dalam Pengelolaan Kreativitas Budaya Sunda di Saung Angklung Udjo}

Keberadaan dan perkembangan Saung Angklung Udjo (SAU) sanagat terkait dengan peran Udjo Ngalagena (1929-2001) 
sebagai pendiri yang merupakan inisiator kreatif. Udjo lahir dan dibesarkan dengan budaya Sunda yang kental dan tumbuh pada jaman dimana pemerintah Hindia Belanda melarang penggunaan angklung secara massal karena permainan ini mampu memompa semangat rakyat untuk melakukan perlawanan. Pemerintah Hindia Belanda melarang permainan angklung secara massal dan hanya boleh dimainkan oleh anak-anak (Azhari, 2011: 5-6).

Kondisi ini tidak menghalangi Udjo untuk menekuni hobinya di bidang seni Sunda, khususnya angklung. Pada awalnya, Udjo mendapat keahliannya melalui proses enkulturasi dan proses sosialisasi dari keluarga dan lingkungan sekitarnya serta dari sekolah. Udjo semakin termotivasi mengembangkan angklung ketika pada tahun 1955 terlibat bersama Daeng Soetigna (Bapak Angklung Indonesia) dalam rangka memeriahkan acara Konferensi Asia Afrika di Bandung. (Syafii, 2009)

Pada tahun 1965, Udjo mulai membuat pertunjukan angklung keliling Bersama beberapa temannya di sela-sela pekerjaannya sebagai guru. Sambutan yang positif dari masyarakat mendorong Udjo lebih serius mengembangkan angklung dengan tujuan utamanya "ingin ikut membina kebudayaan dan kesenian" (Milyartini, 2012). Pada tahun 1966 Udjo Ngalagena membuat sanggar angklung guna merancang suatu lingkungan sosial budaya untuk melestarikan dan mengembangkan seni tradisi Sunda dengan nama Saung Angklung Udjo (SAU).

Pada tahun-tahun selanjutnya, berbagai kreasi dan kreativitas di Saung Angklung Udjo terus tumbuh dan berkembang sehingga menjadikan eksistensinya menguat baik ditingkat lokal maupun nasional bahkan hingga internasional. Di SAU berbagai aktivitas kreatif dalam bentuk pendidikan, pertunjukan, produksi dan berbagai kegiatan lainnya berjalan secara rutin dan terformalkan dengan berbagai atribut yang ada di dalamnya.

Melalui observasi dan wawancara, ditemukan bahwa ada berbagai macam bentuk formalisasi dan ritualisasi yang dilakukan di SAU sejak 54 tahun yang lalu. Udjo mampu menciptakan tradisi baru dalam pertunjukan angklung dan membagi pengetahuannya ke masyarakat sehingga secara bersama-sama, misalnya kebiasaan berlatih, bermain dan membuat angklung yang kemudian menjadi aktivitas rutin dan formal masyarakat di SAU. Tradisi ini telah menjadi keseharian masyarakat sekitar dan berlangsung turun temurun bahkan kini peserta latihan sudah sampai generasi ketiga (cucu). SAU menjadi tempat berkumpul masyarakat dan kehidupan anak-anak sejak puluhan tahun lalu tertuju pada SAU. Sekitar tahun 1970 hingga tahun 2000-an, lebih dari 50\% kehidupan masyarakat sekitar memperoleh dampak dari keberadaan SAU baik dalam bentuk nilainilai sosial budaya, membentuk kebiasaan keseharian aktivitas anak-anak, serta dampak ekonomi yang secara nyata dirasakan masyarakat.

Formalisasi dan ritualisasi di SAU juga dilakukan melalui beberapa aturan, misalnya dalam penggunaan atribut seragam. Penggunaan seragam pada awal-awal berdirinya SAU hanya dikenakan oleh pemain pertunjukan saja. Namun sejak tahun 1980-an, seluruh pegawai, artis dan orangorang yang terlibat di SAU secara rutin menggunakan seragam baju tradisi masyarakat Sunda, laki-laki menggunakan baju pangsi dengan ikat kepala yang disebut totopong sedangkan perempuan menggunakan kebaya. Menariknya karyawan atau pegawai dan pemain boleh menggunakan warna apapun, sehingga ketika pengunjung datang akan melihat seragam tradisional yang berwarna-warni dari yang biasanya bermotif hitam. Saung Angklung Udjo menghadirkan kembali pakaian tradisional dan dijadikannya sebagai seragam kerja. Melalui pakaian maka terlihat pesan yang sangat jelas bahwa SAU memiliki identitas Sunda dan semakin memperkuat nuansa tradisi Sunda.

Pada aspek pertunjukan kesenian juga dilakukan pertunjukan yang terformalkan dan rutin dilakukan setiap sore yaitu pertunjukan 
bambu petang atau Afternoon Bambu Show. Pertunjukan bambu petang akan tetap dilangsungkan dengan berapapun jumlah pengunjung. Pertunjukan ini telah ada sejak tahun 1970-an dan terus ada hingga saat ini. Saat artikel ini di tulis, SAU untuk sementara meliburkan aktivitas pertunjukan karena Covid-19 sejak Maret 2020 namun upaya lain terus dilakukan melalui pengembangan inovasi alat dan pertunjukan angklung virtual baik secara live maupun offline. Pada tanggal 15 Juni 2020 atas izin dan dukungan Pemerintah Kota Bandung, SAU kembali di buka dengan protokol kesehatan yang ketat meski belum terlalu banyak jumlah pengunjung, namun upaya ini patut diapresiasi.

Saung Angklung Udjo hingga saat ini telah dikembangkan untuk menjadi miniatur kampung Sunda yang menghadirkan lingkungan sosial budaya Sunda asli hingga hari ini. Eksistensi SAU sebagai miniatur kampung Sunda semakin kokoh sejak aktivitas produksi, pendidikan dan pertunjukan dikemas untuk kegiatan pariwisata budaya (Musthofa, 2017).

Berbagai kreasi terus terjadi dan berkembang hingga saat ini, dimana SAU dikelola oleh putra-putri dan murid-murid Udjo. Pada konteks kekinian pertunjukan angklung juga telah dikembangkan untuk memainkan beragam jenis musik dalam dan luar negeri seperti musik jazz, pop, dangdut dan berbagai music-musik barat klasik dan kontemporer. Inovasi alat musik dari bambu juga terus dikembangkan seperti grand angklung, angklung toel dan angklung elektronik. Berbagai event juga dilakukan secara rutin misalnya event angklung pride yang diselenggarakan setiap tanggal 16 Nopember untuk memperingati hari ditetapkannya alat musik angklung oleh UNESCO pada tahun 2010 sebagai alat music tradisional warisan budaya tak benda milik Indonesia. Perpaduan antara tradisi dan perkembangan dunia global/modern mulai terlihat sejak dikelola secara lebih profesional dengan manajemen organisasi modern oleh penerus Udjo Ngalagena.

\section{Model Kepemimpinan dalam Pengelolaan Destinasi Wisata Budaya}

Kepemimpinan dalam pengelolaan destinasi wisata di Saung Angklung Udjo sejak awal berdiri hingga tahun 1992 di pegang oleh Udjo Ngalagena. Sosok Udjo Ngalagena dipandang sebagai seorang figur, seorang agensi individu yang memiliki kharisma. Menurut Weber (2012 : 99), kharisma dibagi menjadi dua macam yaitu yang bersifat bawaan lahir dan artifisial. Kharisma artifisial diartikan sebagai kharisma yang dapat dihasilkan secara artifisial pada individu melalui suatu cara yang sulit namun luar biasa menakjubkan.

Kharisma Udjo digolongkan ke dalam kharisma artifisal karena ia berhasil menciptakan suatu karya besar, kreativitas yang mendunia dan dia lahir sebagai anak desa, anak petani bukan keturunan bangsawan. Kharisma tersebut dapat dirasionalisasikan dan dapat dilihat melalui invensi tradisi yang dilakukannya. Melalui kepemimpinan dan invensi tradisi ini, selama lebih dari 50 tahun, apa yang dilakukan dan dibuat oleh Udjo memperoleh dukungan dan kepercayaan dari orang lain. Udjo mampu melakukan banyak terobosan sehingga menciptakan tatanan baru dalam kehidupan sosial ekonomi dan budaya di masyarakat. Melalui pendidikan, produksi dan pertunjukan angklung, Udjo berhasil menciptakan banyak lapangan pekerjaan sehingga berkontribusi dalam mengubah struktur ekonomi masyarakat.

elain Kharismatik, Udjo adalah sosok pekerja keras, disiplin, pembelajar dan sederhana. Udjo Ngalagena memiliki banyak kemampuan sehingga kepemimpinannnya di SAU menjadi faktor yang sangat penting. Pada awal-awal berdirinya Saung Angklung, Udjo sangat disiplin dan anak-anaknya mengatakan bahwa Udjo keras, otoriter, terutama ke anak-anaknya. Sifat-sifat ini seringkali secara otomatis terbawa ke pekerjaan, ke pegawai. Secara leadership Udjo merupakan figur sentral. Udjo memiliki kemampuan dalam bergaul dengan semua lapisan masyarakat, mulai dari masyarakat 
biasa, tetangga sekitar, masyarakat luas, hingga walikota dan gubernur. Sifat keterbukaannya mampu menghilangkan sekat-sekat hubungan sosial dan memudahkan Udjo dalam membangun jaringan. Keterbukaan ini tercermin juga dari keberaniannya untuk meminta maaf tanpa malu mengakui kesalahannya.

Kepemimpinan Udjo Ngalagena menurut Rahmat, seorang pengrajin yang sudah hampir 40 tahun di SAU, adalah kepemimpinan yang menginspirasi, sosok pemimpin yang mampu mengajari, mendidik, menginspirasi orang lain. Salah satu contoh kepemimpinan Udjo, diceritakan oleh Rahmat sebagai berikut, "Kami berdua pernah melakukan suatu perjalanan ke daerah pedalaman di Majalengka. Dari Bandung berangkatnya sekitar jam 10 pagi, sampai di sana sekitar pukul 4 sore. Mau ke tempat bambu sudah terlalu sore dan pasti malam baru sampe, akhirnya terpaksa menginap di suatu rumah yang kebetulan milik salah seorang kenalan Udjo. Besoknya lagi sekitar jam 4 pagi berangkat lagi ke tempat yang dituju dengan jalan kaki sekitar 4 jam. Akhirnya sampai ke tempat bambu tersebut. Setelah urusan selesai, langsung pulang dan selama perjalanan pulang, jika Udjo menemukan bambu yang sudah kering maka diambil, dikumpulkan, diikat dan dibawa ke Bandung. Membawanya juga tidak mudah, harus dipikul dan dinaikkan ke bis. Itulah contoh praktek kepemimpinan yang secara praktis dilakukan Udjo, kepemimpinan dalam perjuangan memperoleh bambu yang berkualitas. Pada zaman dahulu, sebelum tahun 1980-an, mencari bambu masih sulit karena keterbatasan transportasi dan komunikasi, berbeda dengan saat ini. Kalau sekarang sudah enak sekali, hanya tinggal menelpon maka kiriman bambu akan datang. Ada banyak pengalaman yang berkesan bagi Rahmat, sehingga meski Udjo telah tiada, Rahmat tetap berkarya di SAU hingga saat ini.

Posisi Udjo sebagai seorang pemimpin, bukan hanya berhasil mengembangkan SAU, lebih dari itu, Udjo berhasil menggerakan masyarakat dalam aktivitas seni tradisi baik dalam bentuk pendidikan, produksi dan pertunjukan. Meski demikian, Werber mengemukakan bahwa ada kecenderungan dari otoritas kharismatik akan berkurang kekuatannya bila keadaan masyarakat berubah (Soekanto, 2012). Masalah kepemimpinan dalam otoritas kharismatik akan muncul ketika orang yang memiliki kharisma sudah tidak ada lagi. Udjo Ngalagena berhasil mengantisipasi apa yang dikemukakan oleh Soemardjan tersebut dengan melakukan kaderisasi khususnya ke semua anak-anaknya, sehingga regenerasi yang baik berdampak pada transisi dan transformasi organisasi yang lebih baik meski tetap saja ada berbagai permasalahan.

Perkembangan SAU yang semakin besar mengharuskan transformasi manajemen organisasi yang lebih baik. Salah satu tantangan yang berat adalah mengubah manajemen organisasi dari perusahaan keluarga dengan budaya perusahaan kekeluargaan dan kegotong-royongan menjadi perusahaan yang lebih modern dan profesional sehingga dapat berkelanjutan. Perusahaan keluarga bukan berarti tidak baik, hanya kadangkala banyak hal-hal yang sifatnya profesional, kaidah-kaidah dan nilainilai profesional tidak berjalan dengan baik. Hubungan karyawan dengan atasan lebih pada hubungan persaudaraan, tidak ada surat perjanjian kerja, tapi ya berjalan aja. Hal ini sebagaimana dipaparkan oleh putra-putrinya dan sahabat-sahabat Udjo, seperti itulah manajemen di SAU pada awal-awal. Hal ini terjadi karena Udjo seorang seniman, seorang guru, lahir dan dibesarkan dengan suasana kekeluargaan dan persaudaraan dan tidak memiliki banyak ilmu tentang manajemen perusahaan.

Seorang pemimpin yang visioner akan menyiapkan aspek keberlanjutan dan regenerasi organisasi, itulah yang dilakukan Udjo Ngalagena. Udjo menyadari bahwa dirinya tidak selamanya memegang kendali dan kepemimpinan atas SAU. Pada tahun 1992, kepemimpinan SAU mulai dialihkan 
secara perlahan pada anaknya. Saat itu ditunjuklah Udjo Nan Bahagia (putra ketiga) untuk menjadi direktur SAU yang selanjutnya pada tahun 1995 diganti oleh Taufik Hidayat Udjo.

Ketika masa kepemimpinan Taufik pada tahun 1995, sebetulnya grafik jumlah pengunjung di SAU stabil, namun tahun 1997-1998 tiba-tiba turun karena dampak krisis ekonomi sampai tahun 2002-an. Taufik yang merupakan generasi kedua berpikir bagaimana SAU dapat bertahan dan kembali bangkit. Strategi tidak menggantungkan kunjungan turis asing di coba, salah satu caranya adalah materi harus dibedakan, misalnya turis asing cenderung menyukai konsep pertunjukan seni tradisional, sehingga dalam pertunjukan itu selama 2 jam, sekitar 90\% berisi kesenian tradisional, sebaliknya untuk wisatawan dalam negeri maka konten kemasan juga disesuaikan, misalnya permainan angklung ber-genre dangdung, pop, jazz dan lain sebagainya dikembangkan karena model ini yang disukai wisatawan dalam negeri. Upaya ini ternyata memberikan dampak dalam peningkatan jumlah pengunjung SAU.

Saat kondisi pandemik Covid-19 ini, SAU mencoba untuk terus bertahan dengan mengembangkan perangkat dan inovasi angklung khususnya angklung toel dan pertunjukan angklung virtual. Model pengembangan ini berhasil dilakukan meskipun dampak dan keberhasilannya tentunya berbeda dengan dampak saat kondisi normal. SAU juga melakukan berbagai kreasi serta promosi dan kampanye budaya di berbagai platforms sosial media. Penggunaan teknologi informasi kini telah menjadi faktor penting dalam inovasi bisnis pariwisata dan pengelolaan destinasi wisata.

Pada praktik pengelolaan organisasi destinasi wisata SAU, secara organisasi, sejak era Udjo telah ada yayasan dan perusahaan. Pasca kepemimpinan Udjo, generasi anak sudah membangun perusahaan Saung Angklung Udjo dengan manajemen modern, sehingga meskipun secara nyata masih dirasakan adanya nuansa perusahaan keluarga, namun sistem modern dan profesional telah dibangun sehingga saat ini SAU telah bertransformasi menjadi usaha dibidang ekonomi kreatif berbasis sistem manajemen dan administrasi yang modern dan professional, membangun kemitraan dengan dengan masyarakat, perusahaan tour and travel, perusahaan kuliner, perbankan, home industry kerajinan tangan, perusahaanperusahan lain, pemerintah, NGO hingga organisasi internasional. Pada saat yang sama, Yayasan Saung Angklung Udjo juga terus berkembang dan bergerak untuk pelestarian budaya, program edukasi, sosialisasi, pelestarian lingkungan dan berbagai bentuk kegiatan community development.

Dari hasil wawancara dengan pengelola, kehadiran SAU telah memberikan dampak yang besar bagi kesejahteraan masyarakat. Hingga tahun 2019, kurang lebih terdapat 110 mitra pengrajin angklung dan puluhan mitra non-pengrajin. Mitra pengrajin angklung biasanya dalam proses penjualan hasil karya mereka di jadwal setiap pekan dengan pendapatan pengrajin sekitar dua juta rupiah sekali memasok angklung. Dari sisi murid, tahun 2019 ada 500-an murid baru yang mendaftar, jumlah karyawan dan pemain yang rutin terlibat di SAU setiap hari ada kurang lebih 400 orang.

Selama lebih dari 50 tahun, SAU berhasil menggerakan ekonomi masyarakat dan membuat nilai tambah dari seni tradisi angklung. Seni tradisi berhasil berkolaborasi dengan bisnis ekonomi kreatif sehingga menjadi daya tarik wisata budaya. Keberadaan SAU juga berkontribusi besar dalam mengantarkan angklung diakui secara internasional oleh UNESCO.

Kepemimpinan kharismatik Udjo sebagaimana yang dikemukakan oleh Weber (2012) berhasil didukung oleh kompetensi serta ditopang penuh oleh keluarga dan masyarakat sehingga mampu menjadikan SAU sebagai suatu institusi sosial budaya yang keberadaannya diakui oleh masyarakat dunia. Melalui kepemimpinannya, Udjo mampu membentuk struktur sosial dan 
mengembangkan yang menciptakan produk kreativitas berupa pendidikan, produksi, pertunjukan dan aktivitas seni tradisi angklung lainnya yang kemudian menjadi kreativitas bersama masyarakat sehingga terus berkelanjutan.

Melalui pengembangan pariwisata budaya, Udjo mencoba untuk membangkitkan keunikan budaya lokal dalam bentuk seni tradisi, penciptaan lingkungan yang bernuansa Sunda sehingga dapat memperkuat ikatan kebudayaan, dan memberikan akses kepada masyarakat untuk berkreasi dan berkarya. Saung Angklung Udjo sebagai sebuah objek daya tarik wisata tidak luput dari pengaruh globalisasi. Pada perkembangannya, Saung Angklung Udjo mempersiapkan sebuah atraksi wisata budaya yang tidak hanya untuk dinikmati oleh wisatawan lokal tapi juga wisatawan mancanegara. Hal tersebut memacu SAU untuk memberikan pelayanan prima dengan standar internasional dalam setiap atraksi dan pertunjukannya.
Pengaruh globalisasi dan perkembangan pariwisata internasional berdampak pada adanya permintaan akan pertunjukan budaya yang lebih kreatif dan variatif. Hal ini menjadi peluang yang mendorong adanya kreativitas bersama masyarakat untuk mempertunjukan kebudayaan dengan kemasan yang menarik dan kreatif bagi wisatawan domestik dan mancanegara. Melalui pemahaman ini maka SAU berhasil mengemas kebudayaan lokal, mereproduksi, mengkreasikan dan mempromosikan budaya sebagai daya tarik wisata sekaligus sebagai kekayaan yang harus dilestarikan. Peran pemimpin, kreativitas dan dukungan budaya dan masyarakatnya merupakan kunci keberhasilan SAU dalam pelestarian dan pengembangan pariwisata budaya yang berdampak pada kesejahteraan masyarakat sekitar yang berlangsung selama lebih dari 54 tahun.

Secara singkat, tahapan perkembangan model kepemimpinan dan kreativitas di Saung Angklung Udjo dapat dijelaskan dalam tabel berikut:

Tabel 1. Model Kepemimpinan dan Pengelolaan Kreativitas di Saung Angklung Udjo

Kategori
Manajemen
Tipe
Leadership
Sumberdaya
Utama

Periode 1966-1992 Udjo Ngalagena sebagai sentral Otoriter- Dialogis

Bambu, pengrajin dan pemain (anak-anak sekitar)
Periode 1992- 2010

Udjo Ngalagena keluarga Dialogis- Kekeluargaan

Bambu dan berbagai souvenir, pengrajin, pemain, pemain senior dan junior, pegawai

Mitra Utama Masyarakat, komunitas pemerintah, perusahaan travel/ agen perjalanan, petani bambu

\section{Aktivitas Utama}

Produksi, pelatihan, pertunjukan angklung seni,

Masyarakat, pemerintah, perusahaan travel/ agen perjalanan, perbankan, suplayer bambu dan souvenir dari luar kota, komunitas seni dalam dan luar negeri

Produksi, pertunjukkan angklung dan berbagai kesenian sunda, serta promosi dan
Periode 2010-Saat ini

Keluarga \& manajemen organisasi modern

Kekeluargaan- Profesional
Bambu dan berbagai souvenir, pengrajin, pemain, pemain professional, pegawai professional, mitra bisnis, tim desain kreatif, teknologi informasi dan komunikasi (TIK)

Masyarakat, pemerintah, UNESCO, komunitas seni, berbagai suplayer pendukung, biro perjalanan, mitra bisnis, perusahaan EO dalam dan luar negeri

Produksi, pelatihan, pendidikan, pertunjukkan, promosi, pengembangan tim kreatif dan aktivitas 
Tabel 1. Model Kepemimpinan dan Pengelolaan Kreativitas di Saung Angklung Udjo

\begin{tabular}{|c|c|c|}
\hline Kategori & Periode 1966-1992 & $\begin{array}{l}\text { Periode 1992- } 2010 \\
\text { pengembangan wisata } \\
\text { budaya }\end{array}$ \\
\hline $\begin{array}{l}\text { Peran } \\
\text { Masyarakat }\end{array}$ & 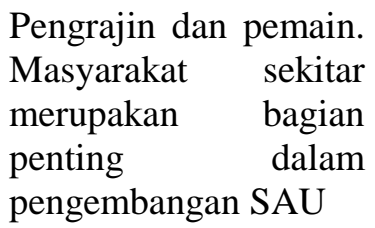 & $\begin{array}{l}\text { Pengrajin, pemain dan } \\
\text { pelatih. Masyarakat } \\
\text { merupakan bagian penting } \\
\text { dalam pengembangan } \\
\text { SAU }\end{array}$ \\
\hline Regenerasi & $\begin{array}{l}\text { Dilakukan oleh Udjo } \\
\text { kepada keluarga }\end{array}$ & $\begin{array}{l}\text { Dilakukan oleh Udjo dan } \\
\text { anak-anaknya } \\
\text { Regenerasi pemain, } \\
\text { pelatih, pengrajin, }\end{array}$ \\
\hline $\begin{array}{l}\text { Kreativitas } \\
\text { dan Inovasi } \\
\text { Produk }\end{array}$ & $\begin{array}{lr}\text { Pertunjukan } & \text { seni } \\
\text { tradisi, } & \text { angklung } \\
\text { pentatonik } & \text { dan } \\
\text { diatonik, } & \text { Arumba } \\
\text { (Alunan } & \text { Rumpun } \\
\text { Bambu), } & \text { wayang } \\
\text { golek, } & \text { angklung } \\
\text { orchestra. } & \end{array}$ & $\begin{array}{l}\text { Pertunjukan seni tradisi } \\
\text { dan musik modern dengan } \\
\text { perkusi angklung di dalam } \\
\text { dan luar negeri secara } \\
\text { rutin, model angklung } \\
\text { gantung, grand angklung, } \\
\text { angklung orchestra, } \\
\text { angklung toel, sekolah } \\
\text { angklung dengan } \\
\text { kurikulum pendidikan } \\
\text { angklung serta souvenir. }\end{array}$ \\
\hline
\end{tabular}

Periode 2010-Saat ini

sosial budaya secara luas, pariwisata kreatif

Pengrajin, pemain, pelatih, mengembangkan usaha pendukung (Souvenir, rumah makan, akomodasi dan transportasi, dll). Masyarakat merupakan bagian penting dalam pengembangan SAU

Tersusun sistem regenerasi pendidikan, pelatihan yang terlembagakan serta manajemen SDM yang profesional

Pertunjukan seni tradisi dan modern dengan perkusi angklung di dalam dan luar negeri secara rutin, grand angklung, angklung orchestra \& jazz, Angklung Toel Elektrik, Akademi angklung, festivalisasi angklung, angklung virtual serta pengemasan pertunjukan melalui multi media dan multi platform.

\section{SIMPULAN}

Perkembangan zaman dan globalisasi budaya memberikan banyak peluang jika ada proses kreatif terus berjalan di masyarakat dan di dukung oleh model kepemimpinan yang tepat. Pada kasus ini, model kepemimpinan Udjo Ngalagena berperan sangat signifikan dalam sinergi pelestarian budaya dan pariwisata di Saung Angklung Udjo. Model kepemimpiann Udjo Ngalagena adalah model kharismatik yang kemudian seiring perkembangan organisasi maka model pengelolaan di transformasikan dalam organisasi profesional dan tata kelola modern. Melalui kepemimpinan kharismatik dan kreativitasnya, Udjo mampu menginvensi seni tradisi lokal dan mengembangan destinasi wisata budayanya sehingga memberikan berbagai dampak positif bagi masyarakat.

Selanjutnya, SAU dapat berkembang hingga lebih dari 54 tahun karena adanya dukungan masyarakat dan budayanya, regenerasi kepemimpinan, pengembangan kreativitas yang terus menerus, adaptable dengan perkembangan zaman, khususnya perkembangan industri pariwisata global dan perkembangan ekonomi kreatif serta pemanfaatan teknologi informasi yang optimal. Selain itu, hal yang tidak kalah 
pentingnya adalah adanya dampak positif secara ekonomi dan budaya yang secara signifikan dan nyata dirasakan oleh masyarakat sekitar dan masyarakat luas pada umumnya.

\section{REFERENSI}

Dokumen \& Data Kegiatan Saung Angklung Udjo

Dokumen Profil Saung Angklung Udjo

Dokumen Video. http://www.angklungudjo.co.id

Creswell, J.W. (2010). Research Design : Pendekatan Kualitatif, Kuantitatif, dan Mixed. Yogyakarta: Pustaka Pelajar

Gunawijaya, J. (2011). Tatali Paranti Karuhun: Invensi Tradisi Komunitas Kasepuhan Gunung Halimun Di Sukabumi, Jawa Barat. Disertasi Doktor Tidak Diterbitkan. Depok: Jurusan Antropologi FISIP UI [Universitas Indonesia].

Hobsbawm, Eric. (2000). Introduction: Inventing Traditions", dalam Eric Hobsbawm dan Terence Ranger (ed.), The Invention of Tradition, Cambridge University Press.

Ife, Jim. (2013). Community Development In An Uncertain World. New York. USA. Cambridge University Press.

Masook, N.K. (2011) Creativity, Self-Leadership and Individual Innovation. The Journal of Commerce ISSN: 2220-6043 Hailey College of Commerce, University of the Punjab, Pakistan.

Milyartini, R. A. (2012). Model Transformasi Nilai Budaya Melalui Pembinaan Seni di Saung Angklung Udjo Untuk Ketahanan Budaya. Disertasi.

Program Studi Pendidikan Umum/Nilai. Sekolah Pasca Sarjana
Universitas Pendidikan Indonesia, Bandung.

Moersid, A. F. (2013). Re-Invensi Batik dan Identitas Indonesia Dalam Arena Pasar Global. Fakultas Seni Rupa Institut Kesenian Jakarta.

Munandar, U. (2012). Pengembangan Kreativitas Anak Berbakat. Jakarta: Rineka Cipta.

Musthofa, B. M., \& Gunawijaya, J. (2017). Saung Angklung Udjo: Invensi Tradisi Lokal yang Mendunia. Jurnal Antropologi Indonesia, 136-149.

Retrieved https: //doi/org/10.7454/ai.v38i2.8776.

Musthofa, B. M. (2019)

Pengembangan Budaya Menuju Kesejahteraan Budaya : Pelajaran Dari Pengembangan Masyarakat Di Saung Angklung Udjo, Bandung, Jawa Barat. Sosio Informa, [S.1.], v. 4, n. 3. ISSN 2502-7913. Retrieved doi: https://doi.org/10.33007/inf.v4i3.160 $\underline{0}$.

Neuman, W. L. (2013) Social Research Method: Qualitative and Quantitative Approaches. Boston: Allyn \& Bacon

Rahmanisa, W. N. (2014). Invensi Tradisi: Atraksi Wisata Berbasis Pelestarian dan Pengembangan Sanggar Kesenian Saung Angklung Udjo, Bandung, Jawa Barat", Skripsi, Departemen Antropologi, Fakultas Ilmu Sosial Dan Ilmu Politik, Depok

Richards, G (1996). Cultural Tourism in Europe. Wallingford, CAB International.

Ritzer G \& Douglas J. Goodman. (2004). Teori Sosiologi Modern. Jakarta: Prenanda Media. 
Robbins, S. P. (2017). Perilaku Organisasi. Edisi 16. Index. Jakarta.

Shahab, Y. Z. (2001). Rekacipta Tradisi Betawi: Sisi Otoritas dalam Proses Nasionalisasi Tradisi Lokal. Jurnal Antropologi Indonesia No 66. FISIP UI.

Shahab, Y.Z. (2004). Identitas dan Otoritas: rekonstruksi Tradisi Betawi. Depok: Lab. Antropologi FISIP UI.

Soekanto, S. (2012). Sosiologi Suatu Pengantar. Jakarta: Rajawali Pers.

Soemardjan, S. (1983). Kreativitas, Suatu Tinjauan dari Sosiologi, dalam Sutan Takdir Alisyahbana (ed.), Kreativitas. Jakarta: Penerbit Dian Rakyat.

Syafii, S. (2009). Udjo Diplomasi

Angklung. Jakarta: PT Grasindo.

Undang-Undang No 10 tahun 2009 tentang Kepariwisataan

Weber, Max. (2012). Sosiologi Agama (terj). Yogyakarta: IRCiSoD

\section{BIODATA PENULIS}

Budiman Mahmud Musthofa saat ini bekerja sebagai dosen tetap pada Prodi Pariwisata Program Pendidikan Vokasi Universitas indonesia.

Sinta ID

6030123 